\title{
Neurophobia in Brazil: Detecting and Preventing a Global Issue
}

\section{Neurofobia no Brasil: Detectando e Prevenindo um Problema Global}

\author{
Bruno Lopes Santos-Lobato ${ }^{l, I I}$ \\ Átila Barros Magalhães ${ }^{I I I}$ \\ Diego Goes Moreira ${ }^{I V}$ \\ Fredison Pinheiro Farias ${ }^{I V}$ \\ Lara Khaled Porto ${ }^{V}$ \\ Rodrigo Bentes Pereiral \\ Sávio Sérgio Custódio ${ }^{V}$ \\ Tiago Kiyoshi Kitabayashi Bragal
}

\section{KEY WORDS}

- Neurology.

- Education

- Brazil.
REVISTA BRASILEIRA DE EDUCAÇÃO MÉDICA

\begin{abstract}
Neurophobia is a global issue known as a fear of Neurology and Neurosciences by medical students and physicians, and it may contribute to a reduced number of trained neurologists and a global misunderstanding of neurological diseases among physicians. To date, there are no studies that address the issue of Neurophobia in Brazil. The present study aimed to evaluate the perception of Neurology and Neurosciences among Brazilian medical students. Students from four medical schools in the state of Pará, in the second (pre-clinical phase), fourth (clinical phase) and sixth (internship) years of the course, were submitted to a self-administered and written questionnaire divided into two sections: the first section included questions assessing their perceived level of interest, level of knowledge, degree of difficulty, confidence in examining patients, quality of teaching in medical school and likelihood of pursuing the career, concerning different clinical specialties (Cardiology, Endocrinology, Gastroenterology, Nephrology, Neurology, Respiratory Medicine and Rheumatology). In the second section, there were questions about possible reasons why Neurology was perceived as a difficult subject and possible ways to improve neurological education. A total of 486 questionnaires were completed. Neurology was perceived as the most difficult clinical specialty (mean score 4.00; $p<0.001$ ), in which students feel least confident about conducting physical examinations (mean score $2.97 ; p<0.001$ ), and with the worst quality of teaching (mean score 3.12; $p<0.001$ ). The main cause of Neurophobia was the need to know neuroanatomy and neurophysiology (very important reason for $39.4 \%$ of students), and the most frequently suggested method to improve neurological education was through more and better bedside tutorials (very important factor - 53.3\%). Students developing extracurricular activities, women and older students had more unfavorable opinions about Neurology. Neurophobia is also present in Brazil, and new educational approaches must be proposed to improve the misperception of Neurology by medical students. The Medical Education Commission of the Brazilian Academy of Neurology should propose guidelines on Neurology teaching at undergraduate level.
\end{abstract}

\footnotetext{
State University of Pará, Belém, PA, Brazil.

${ }^{I I}$ Medical School, University of São Paulo, RibeirãoPreto, SP, Brazil.

III State University of Pará, Santarém, PA, Brazil.

${ }^{I V}$ Federal University of Pará, Belém, PA, Brazil.

${ }^{v}$ University Center of Pará, Belém, PA, Brazil.
} 


\section{PALAVRAS-CHAVE}

- Neurologia.

- Educação.

- Brasil.

\section{RESUMO}

A Neurofobia é um problema global conhecido como uma aversão à Neurologia e às Neurociências por parte de estudantes de Medicina e médicos, podendo contribuir para que se forme um número reduzido de neurologistas e que haja um desconhecimento global sobre manejo de doenças neurológicas entre médicos. Até o momento, não existem estudos sobre Neurofobia no Brasil. O objetivo do presente estudo foi avaliar a percepção de Neurologia e Neurociências entre estudantes de Medicina no Brasil. Estudantes de quatro escolas médicas no Estado do Pará, matriculados no segundo ano (fase pré-clínica), quarto ano (fase clínica) e sexto ano (internato), responderam a um questionário autoaplicado, dividido em duas partes: a primeira incluiu perguntas sobre o nível de interesse, nível de conhecimento, grau de dificuldade, confiança ao examinar pacientes, qualidade das aulas no curso médico e probabilidade de seguir carreira, envolvendo diferentes especialidades clínicas (Cardiologia, Endocrinologia, Gastroenterologia, Nefrologia, Neurologia, Pneumologia e Reumatologia). Na segunda parte, foram feitas perguntas sobre possíveis razões para a Neurologia ser vista como uma disciplina difícil e sobre possíveis maneiras de melhorar a educação neurológica. Foram preenchidos 486 questionários. A Neurologia foi percebida como a disciplina mais difícil (pontuação média 4.00; $p<0.001$ ), em que há menos confiança no exame físico (pontuação média 2.97; $p<0.001$ ) e a de pior qualidade de aulas (pontuação média 3.12; $p<0.001$ ). O principal motivo da Neurofobia foi a necessidade de saber Neuroanatomia e Neurofisiologia (razão muito importante para 39,4\% dos estudantes), e a sugestão mais importante para melhorar a educação neurológica foi aumentar a quantidade e a qualidade das aulas práticas (fator muito importante - 53,3\%). Estudantes envolvidos em atividades extracurriculares, do sexo feminino e mais velhos têm opiniões mais desfavoráveis a respeito da Neurologia. A Neurofobia está também presente no Brasil, e novas abordagens educacionais devem ser propostas para melhora da atual percepção desfavorável da Neurologia por estudantes de Medicina. Sugerimos que a Comissão de Educação Médica da Academia Brasileira de Neurologia proponha diretrizes para o ensino de Neurologia na graduação.

Recebido em: 14/03/2017

Aprovado em: 21/03/2017

\section{INTRODUCTION}

Medical students and physicians around the world complain about a fear of Neurology. This aversion results in fewer numbers of neurologists and general physicians with limited knowledge of Neurology and Neurosciences. In 1994, Ralph F. Josefowicz first coined the term "Neurophobia" to describe this common feeling ${ }^{1}$, and many authors have reported and measured its features ${ }^{2-10}$. Neurophobia has already been characterized in Asia, Europe, Africa, North America and the Caribbean. In South America, a recent study described high frequencies of inappropriate decisions in neurological diseases by students ${ }^{11}$, however, no analyses regarding the perception of Neurology and Neurosciences have been published to date.

There is regional inequality in the distribution of neurologists in Brazil; the majority of these specialists live in the southeast region of the country and in state capitals. In 2014, regions such as the Brazilian Amazon showed an average of 0.68 neurologists per 100,000 inhabitants, the lowest ratio in the country ${ }^{12}$. Neurophobia may contribute to a reduced number of trained neurologists and a global misunderstanding of neurological diseases among physicians. To prevent the current shortage of neurologists in Brazil from worsening, it is essential to investigate the causes of Neurophobia and how to avoid it in medical schools. The present study is the first Brazilian survey to determine the perception of Neurology and Neurosciences among medical students in four medical schools in the state of Pará.

\section{METHODS}

\section{Study design and sample}

This cross sectional study was conducted from May to December 2015 at four medical schools in the state of Pará: the Federal University of Pará, the State University of Pará at Belém, the State University of Pará at Santarém and the University Center of Pará. Brazilian medical schools have a six-year curriculum: two years of biomedical sciences, two years of clinical training 
and two years of internship rotations. The participants in the study were students from second (pre-clinical phase), fourth (clinical phase) and sixth (internship) years of medical school. All four institutions approved the study.

\section{Instrument}

To evaluate the perception of Neurology and Neurosciences, causes of misperception and suggestions for how to improve the teaching of these disciplines, we used a self-administered and written questionnaire based on previous studies ${ }^{2,8,9}$ divided into two sections. The first section assessed the perceived level of interest, level of knowledge, degree of difficulty, confidence in examining patients, quality of teaching at medical school and likelihood of pursuing a career in the specialty. For example: "What is your current level of interest in...", or "Do you think the discipline is easy or difficult?" The responses were ranked on a maximum Likert scale of 5 (' 1 ' - lowest possible score and ' 5 ' - highest possible score; the scale was inverted for the "degree of difficulty" question). The following seven specialties were considered: Cardiology, Endocrinology, Gastroenterology, Nephrology, Neurology, Respiratory Medicine and Rheumatology.

In the second section, participants were asked to rate selected reasons why Neurology was perceived as a difficult subject and possible ways to improve neurological education. For example: "Neurology may be difficult for a number of reasons. Please rate the importance of the possible reasons," or "Please rate the utility of the following methods as possible alternatives to improve neurological education". These selected options had been previously used ${ }^{9}$. Responses were ranked on a maximum Likert scale of 4 (' 1 ' - lowest possible score and ' 4 ' - highest possible score). Finally, we asked participants to answer one open-ended question about how teaching in Neurology and Neurosciences could be improved. Age, gender, medical school year and extracurricular activities were also registered.

Following regular lectures, questionnaires were distributed to the students who accepted participating in the survey and were asked not to indicate their names. Questionnaires with less than $50 \%$ of the questions answered were excluded.

\section{Statistical analysis}

Analyses were performed using SPSS version 16.0.0 and Prism version 5.0 (both for Windows). Normal data were described as mean \pm SEM. Differences between three or more independent samples were calculated using Kruskal-Wallis test and Dunn procedures for multiple comparisons (continuous variables) or $\mathrm{X}^{2}$ test (categorical variables). Multivariate logistic re- gressions were performed, with the dependent variable being the presence of Neurophobia in the questions of the first section of the questionnaire, and the independent variables being age, sex and extracurricular activities. For the dependent variable, values $<2$ were regarded as presence of Neurophobia and $>3$ as absence of Neurophobia (for "degree of difficulty", values $<2$ corresponded to absence of Neurophobia and $>2$ to presence of Neurophobia). Differences were considered significant when $\mathrm{p}<0.05$.

\section{RESULTS}

A total of 486 questionnaires were completed, and the participation per medical course year was as follows: second year - 224 (46\%; female 55.3\%); fourth year - 167 (34.3\%; female $53.2 \%)$; sixth year - $95(19.5 \%$; female $55.7 \%)$. The mean age of the participants was $22.7 \pm 0.15$ (second year - 21.3 \pm 0.21 ; fourth year $-23.1 \pm 0.24$; sixth year $-25.1 \pm 0.3$ ) (Table 1 ). The response rate was $55.1 \%$ (second year $-67 \%$; fourth year $-55 \%$; sixth year $-37 \%$ ), representing approximately $18 \%$ of all medical students in the state of Pará.

\begin{tabular}{|c|c|c|c|c|c|c|}
\hline Breakdow & & cal sc & $\begin{array}{l}\text { BLE } \\
\text { ol st }\end{array}$ & ents $i$ & $\operatorname{ach} y$ & r by sex \\
\hline Medical & & & & ale & Total & $p$ value* \\
\hline school year & n & $\%$ & n & $\%$ & & \\
\hline 2nd year & 100 & 44.64 & 124 & 55.36 & 224 & NS \\
\hline 4 th year & 78 & 46.71 & 89 & 53.29 & 167 & NS \\
\hline 6th year & 42 & 44.21 & 53 & 55.79 & 95 & NS \\
\hline
\end{tabular}

* $p$ value for difference regarding gender among medical students from three year groups ( $\mathrm{X}^{2}$ test). NS, non-significant

Neurology was perceived as the most difficult discipline (4.00; $\mathrm{p}<0.001$, Figure 1A), in which they had the least confidence when examining patients (2.97; $\mathrm{p}<0.001$, Figure $1 \mathrm{~B})$ and the worst quality of teaching (3.12; $\mathrm{p}<0.001$, Figure $1 \mathrm{C})$ among seven clinical specialties. Interest in Neurology was considerable $(2.78$, third place; $\mathrm{p}<0.001$, Figure 1D) and the level of knowledge was limited $(2.49$, fourth place; $\mathrm{p}<0.001$, Figure 1E). Neurology was the first career choice for $19.4 \%$ of the students (decreasing frequency -second year - 22\%; fourth year $-18.2 \%$; sixth year $-15.3 \%$ ) and the last choice for $27.2 \%$ (increasing frequency -second year - 23.9\%; fourth year $28.7 \%$; sixth year $-34.6 \%$ ), but differences were not significant $\left(X^{2}=2.67, p=0.26\right)$. Comparing the three different moments of medical school (Figure 2), over $70 \%$ of the students in the second, fourth and sixth medical school year graded Neurology as "difficult" and "very difficult" (Figure 2A), with no differences between the groups. There were differences between 
the second, fourth and sixth year in terms of confidence in examining patients $\left(X^{2}=7.89, p=0.01\right.$; Figure $\left.2 B\right)$, quality of teaching $\left(X^{2}=29.23, p<0.001\right.$; Figure $\left.2 C\right)$, level of knowledge $\left(X^{2}=6.35, p=0.04\right.$; Figure 2E) and likelihood of specializing in Neurology $\left(\mathrm{X}^{2}=6.44, \mathrm{p}=0.04\right.$; Figure $\left.2 \mathrm{~F}\right)$ - unfavorable opinions about Neurology were more common in the final years of the medical course.

\section{Figure 1}

Mean survey score results of seven clinical specialties (red bar represents Neurology). (A) Level of difficulty.

(B) Confidence in examining patients. (C) Quality of teaching. (D) Level of interest. (E) Level of

knowledge. * p value for comparison to Neurology

$<$ 0.05. Car, Cardiology; End; Endocrinology; Gas,

Gastroenterology; Nep, Nephrology; Neu, Neurology;

Res, Respiratory Medicine; Rhe, Rheumatology
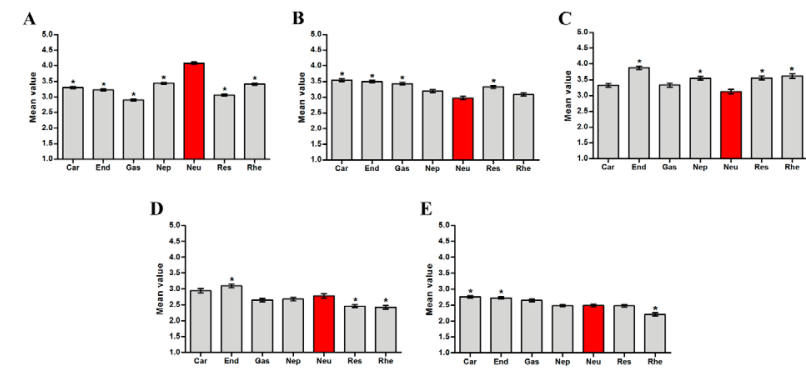

\section{Figure 2}

Comparison of the frequencies of opinions about

Neurology between three years of medical school (second, fourth and sixth year). (A) Level of difficulty.

(B) Confidence in examining patients. (C) Quality of teaching. (D) Level of interest. (E) Level of knowledge. (F) Likelihood of pursuing career in the specialty. Blue stacked bar, favorable opinion about Neurology; gray stacked bar, moderate opinion about Neurology; red stacked bar, unfavorable opinion about Neurology
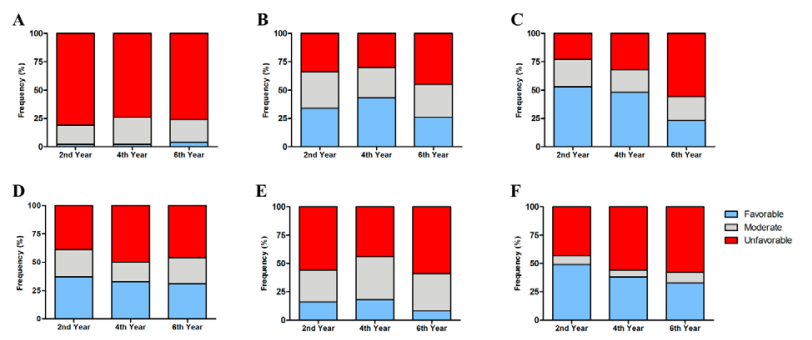

Concerning the causes of Neurophobia, the most important contributor to the perception of Neurology as difficult was the need to understand neuroanatomy and neurophysiology (very important reason to $39.4 \%$ of students), which was more frequently reported in the clinical and internship periods (second year $-37.9 \%$; fourth year $-74.4 \%$; sixth year - 71.2\%) (Table 2). Limited exposure to neurological patients and a large number of rare and difficult diagnoses were considered as the second and third most important contributors, respectively. The most important contributor for second year students was the large number of rare and difficult diagnoses $(60.9 \%)$, whereas for fourth year students it was the need to understand neuroanatomy and neurophysiology (74.4\%) and for sixth year students it was not enough teaching $(74.4 \%)$.

\begin{tabular}{|c|c|c|c|c|c|}
\hline \multicolumn{6}{|c|}{$\begin{array}{l}\text { TABLE } 2 \\
\text { Reasons for Neurology being perceived as a } \\
\text { difficult subject. Frequencies show proportion } \\
\text { of answers rating these options as important } \\
\text { and very important factors for Neurophobia }\end{array}$} \\
\hline & \multicolumn{4}{|c|}{ Frequency $(\%)$} & \multirow{2}{*}{$p$ value* } \\
\hline & $\begin{array}{l}\text { Second } \\
\text { year }\end{array}$ & $\begin{array}{l}\text { Fourth } \\
\text { year }\end{array}$ & $\begin{array}{l}\text { Sixth } \\
\text { year }\end{array}$ & Total & \\
\hline $\begin{array}{l}\text { Need to understand } \\
\text { Neuroanatomy and } \\
\text { Neurophysiology }\end{array}$ & 37.9 & 74.4 & 71.2 & 74.2 & $<0.001$ \\
\hline $\begin{array}{l}\text { Having a complex } \\
\text { clinical examination }\end{array}$ & 55.1 & 57.3 & 54.7 & 55.8 & 0.03 \\
\hline $\begin{array}{l}\text { Having a reputation of } \\
\text { being difficult }\end{array}$ & 26.9 & 35.5 & 28.7 & 30.2 & $<0.001$ \\
\hline $\begin{array}{l}\text { Having large number } \\
\text { of complex and rare } \\
\text { diagnosis }\end{array}$ & 60.9 & 61.2 & 42.5 & 57.4 & $<0.001$ \\
\hline Being poorly taught & 35.4 & 44.8 & 71.5 & 45.8 & $<0.001$ \\
\hline $\begin{array}{l}\text { Not having enough } \\
\text { teaching time }\end{array}$ & 44 & 52.4 & 74.4 & 52.9 & $<0.001$ \\
\hline $\begin{array}{l}\text { Limited exposure to } \\
\text { neurological patients }\end{array}$ & 57 & 56.9 & 72.6 & 60 & 0.02 \\
\hline $\begin{array}{l}\text { Not having definitive } \\
\text { or curative treatment } \\
\text { in most instances }\end{array}$ & 38.7 & 37.9 & 34.7 & 37.6 & NS \\
\hline
\end{tabular}

* $p$ value for difference of opinions among medical students from three year groups ( $\mathrm{X}^{2}$ test). NS, non-significant

According to the students, when answering both the Likert-style question and open-ended question, the most important methods to improve Neurology and Neurosciences teaching and learning were more/better bedside tutorials (very important factor $-53.3 \%$ ) and more/better traditional lectures (very important factor $-46.9 \%$ ) (Table 3 ). Pre-clinical students believed more in online resources $\left(X^{2}=6.57, p=0.03\right)$ and textbooks $\left(X^{2}=20.34, p<0.001\right)$ as learning tools. About $30 \%$ of students did not answer the open-text suggestions. 


\section{TABLE 3}

Methods to improve Neurology and Neurosciences

teaching and learning. Frequencies show proportion of answers rating these options as important and very important factors to Neurophobia

\begin{tabular}{|c|c|c|c|c|c|}
\hline & \multicolumn{4}{|c|}{ Frequency (\%) } & \multirow{2}{*}{$\begin{array}{c}p \\
\text { value* }\end{array}$} \\
\hline & $\begin{array}{l}\text { Second } \\
\text { year }\end{array}$ & $\begin{array}{c}\text { Fourth } \\
\text { year }\end{array}$ & $\begin{array}{l}\text { Sixth } \\
\text { year }\end{array}$ & Total & \\
\hline $\begin{array}{l}\text { More and better } \\
\text { online resources }\end{array}$ & 50 & 39.7 & 36.2 & 43.8 & 0.03 \\
\hline $\begin{array}{l}\text { More and better } \\
\text { access to textbooks }\end{array}$ & 75.6 & 54 & 60.4 & 65.3 & $<0.001$ \\
\hline $\begin{array}{l}\text { More and better } \\
\text { traditional lectures }\end{array}$ & 77.9 & 76.2 & 85.7 & 78.8 & NS \\
\hline $\begin{array}{l}\text { More and better } \\
\text { bedside tutorials }\end{array}$ & 82.4 & 88.2 & 85.7 & 85 & NS \\
\hline $\begin{array}{l}\text { More and better } \\
\text { peer discussions }\end{array}$ & 67.5 & 73.9 & 67 & 69.6 & NS \\
\hline
\end{tabular}

* $p$ value for difference of opinions among medical students from three year groups $\left(X^{2}\right.$ test). NS, non-significant

To assess the influence of some variables on the unfavorable opinion about Neurology in the six questions of the first section of the questionnaire, we performed multivariate lo- gistic regression analyses adjusted for age, gender and extracurricular activities for each question (Table 4). Women held more unfavorable opinions about Neurology than men in the questions "level of interest" (OR 1.96, 95\% CI 1.2-2.9), "confidence in examining patients" (OR 1.89, 95\% CI 1.2-2.9) and "likelihood of pursuing career" (OR 2.11, 95\% CI 1.32-3.37). Older students had more unfavorable opinions than younger students in the questions regarding "quality of teaching" (OR $1.08,95 \%$ CI 1.0-1.17) and "likelihood of pursuing career" (OR 1.09 , 95\% CI 1.01-1.17). Students with extracurricular activities had more unfavorable opinions in the questions regarding "level of knowledge" (OR 1.98, 95\% CI 1.1-3.57) and "quality of teaching" (OR 2.7, 95\% CI 1.43-5.0). No multicollinearity was found between independent variables.

\section{DISCUSSION}

This is the first investigation into perceptions of Neurology among medical students in Brazil. Our results showed students from the four medical schools of Pará perceive Neurology as the most difficult clinical specialty, with the worst quality of teaching and which they feel the least confidence in examining patients. These indicators suggest the presence of

\begin{tabular}{|c|c|c|c|c|c|}
\hline \multicolumn{6}{|c|}{$\begin{array}{l}\text { Multivariate analysis (unconditional logistic regression) adjusted for the presence } \\
\text { of Neurophobia in the questions of first section of the questionnaire }\end{array}$} \\
\hline & Variable & Constant & Adjusted OR & $95 \% \mathrm{CI}$ & $p$ value \\
\hline $\begin{array}{l}\text { Level of interest } \\
(\mathrm{n}=378)\end{array}$ & $\begin{array}{l}\text { Sex } \\
\text { Age }^{*} \\
\text { Extracurricular activities }\end{array}$ & $\begin{array}{l}0.67 \\
0.04 \\
0.31\end{array}$ & $\begin{array}{l}1.96 \\
1.04 \\
0.73\end{array}$ & $\begin{array}{r}1.28-2.98 \\
0.9-1.12 \\
0.44-1.22\end{array}$ & $\begin{array}{l}0.002 \\
0.16 \\
0.23\end{array}$ \\
\hline $\begin{array}{l}\text { Level of knowledge } \\
(\mathrm{n}=328)\end{array}$ & $\begin{array}{l}\text { Sex } \\
\text { Age }^{*} \\
\text { Extracurricular activities }\end{array}$ & $\begin{array}{l}0.17 \\
0.03 \\
0.68\end{array}$ & $\begin{array}{l}1.18 \\
1.03 \\
1.98\end{array}$ & $\begin{array}{r}0.69-2.02 \\
0.95-1.12 \\
1.1-3.57\end{array}$ & $\begin{array}{l}0.52 \\
0.38 \\
0.02\end{array}$ \\
\hline $\begin{array}{l}\text { Level of difficulty } \\
(\mathrm{n}=384)\end{array}$ & $\begin{array}{l}\text { Sex } \\
\text { Age }^{*} \\
\text { Extracurricular activities }\end{array}$ & $\begin{array}{l}0.26 \\
0.11 \\
1.02\end{array}$ & $\begin{array}{l}1.3 \\
1.12 \\
2.77\end{array}$ & $\begin{array}{l}0.4-4.16 \\
0.91-1.38 \\
0.85-9.0\end{array}$ & $\begin{array}{l}0.65 \\
0.27 \\
0.09\end{array}$ \\
\hline $\begin{array}{l}\text { Confidence in examining patients } \\
(\mathrm{n}=335)\end{array}$ & $\begin{array}{l}\text { Sex } \\
\text { Age }^{*} \\
\text { Extracurricular activities }\end{array}$ & $\begin{array}{l}0.63 \\
0.03 \\
0.22\end{array}$ & $\begin{array}{l}1.89 \\
1.03 \\
1.25\end{array}$ & $\begin{array}{l}1.22-2.94 \\
0.96-1.1 \\
0.71-2.19\end{array}$ & $\begin{array}{l}0.004 \\
0.35 \\
0.42\end{array}$ \\
\hline $\begin{array}{l}\text { Quality of teaching } \\
(\mathrm{n}=282)\end{array}$ & $\begin{array}{l}\text { Sex } \\
\text { Age }^{*} \\
\text { Extracurricular activities }\end{array}$ & $\begin{array}{r}-0.14 \\
0.08 \\
0.99\end{array}$ & $\begin{array}{l}0.86 \\
1.08 \\
2.7\end{array}$ & $\begin{array}{c}0.53-1.4 \\
1.0-1.17 \\
1.43-5.0\end{array}$ & $\begin{array}{l}0.55 \\
0.04 \\
0.002\end{array}$ \\
\hline $\begin{array}{l}\text { Likelihood of pursuing career in the specialty } \\
(\mathrm{n}=304)\end{array}$ & $\begin{array}{l}\text { Sex } \\
\text { Age }^{*} \\
\text { Extracurricular activities }\end{array}$ & $\begin{array}{r}0.74 \\
0.09 \\
-0.09\end{array}$ & $\begin{array}{l}2.11 \\
1.09 \\
0.9\end{array}$ & $\begin{array}{l}1.32-3.37 \\
1.01-1.17 \\
0.52-1.5\end{array}$ & $\begin{array}{l}0.002 \\
0.01 \\
0.72\end{array}$ \\
\hline
\end{tabular}

*Quantitative variable 
Neurophobia in Brazil, as already reported in other countries. This is also the first study to analyze the differences of Neurophobia among students from pre-clinical, clinical and internship stages of study, and to seek predictors of Neurophobia by means of logistic regression.

Six previous studies already identified that Neurology is seen as the most difficult clinical specialty ${ }^{2,3,4,6,8,10}$ (Table 5). Compared to the other questions, the one regarding the student's perception of the degree of difficulty seems to be the best question to recognize Neurophobia in a student sample. Furthermore, confidence in examining neurological patients was the worst in the four studies, as compared to other clinical specialties ${ }^{2,3,6,10}$. A moderate perception of interest and knowledge was also previously described ${ }^{2,3,4,8}$ and, even so, Neurology was the first choice clinical specialty for one fifth of the students, similar to the findings of an Indian study ${ }^{7}$. Flanagan et al. ${ }^{3}$ explained the disparity between difficulty and knowledge/interest by the fact that students perceive that they have to struggle more at Neurology to gain knowledge. Gupta et al. ${ }^{7}$ showed two factors influenced medical students' choice of Neurology as a career: intellectual challenge (73\%) and inspiration by Neurology teachers $(63 \%)$. cording to a recent survey, the state of Pará had 0.53 neurologists per 100,000 inhabitants in 2014, half of the minimum rate of 1 neurologist per 100,000 inhabitants recommended by the World Health Organization ${ }^{12}$. In the Brazilian Amazon, referral mechanisms from primary to tertiary care are slow and obsolete, and transport of patients from the hinterland to larger cities, where the majority of the neurologists live, is impaired by infrastructural limitations ${ }^{14}$. Besides the possible low degree of effective GP management of neurological disorders, Neurophobia can also be detrimental for the training of new neurologists.

A need to understand neuroanatomy and neurophysiology was seen as the most important reason for Neurophobia. The same top reason was described in previous studies ${ }^{2,4,5,6,8}$. But is detailed knowledge of neurosciences really necessary to practice Neurology? Zinchuk et al. ${ }^{6}$ reported that residents perceived neuroanatomy as a minor contributor to the difficulty of Neurology compared to students ${ }^{6}$, however our results and data from Matthias et al. ${ }^{8}$ showed students in clinical and internship stages described knowledge of neurosciences as essential to Neurophobia. Some authors argue a thorough knowledge of neuroanatomy may not be essential

TABLE 5

Previous studies in Neurophobia compared with our data. After the mean score, the position of Neurology in comparison to other clinical specialties is given (between parentheses)

\begin{tabular}{|c|c|c|c|c|c|c|}
\hline Author, year & Country & Sample, $\mathbf{n}$ & $\begin{array}{l}\text { Mean - Level } \\
\text { of difficulty }\end{array}$ & $\begin{array}{l}\text { Mean - Confidence } \\
\text { in examining }\end{array}$ & $\begin{array}{l}\text { Mean - Level } \\
\text { of knowledge }\end{array}$ & $\begin{array}{l}\text { Mean - Level } \\
\text { of interest }\end{array}$ \\
\hline Schon et al., 2002 & England & 345 & 3.8 (1st) & 2.7 (7th) & 2.4 (7th) & $3.3(3 \mathrm{rd})$ \\
\hline Flanagan et al., 2007 & Ireland & 457 & 3.1 (1st) & NA (8th) & NA (4th) & NA \\
\hline Youssef et al., 2009 & Trinidad and Tobago & 167 & 3.8 (1st) & NA & 2.3 (7th) & 2.5 (5th) \\
\hline Sanya et al., 2010 & Nigeria & 302 & NA & NA & 2.4 (7th) & NA \\
\hline Zinchuk et al., 2010 & USA & 152 & 2.7 (1st) & 2.6 (8th) & 2.7 (8th) & NA \\
\hline Mathias et al., 2013 & Sri Lanka & 248 & 3.4 (1st) & NA & 2.5 (5th) & 2.8 (3rd) \\
\hline McMarron et al., 2014 & Ireland & 118 & NA & NA & NA & NA \\
\hline Pakpoor et al., 2014 & United Kingdom & 2877 & 3.4 (1st) & 2.9 (7th) & NA & NA \\
\hline Santos-Lobato et al., 2016 & Brazil & 486 & 4.0 (1st) & 2.7 (7th) & 2.4 (4th) & 2.7 (3rd) \\
\hline
\end{tabular}

NA, not available

Neurophobia has also been described in general practitioners $(\mathrm{GP})^{2,3,8}$ and it can worsen the quality of global neurological care. GPs affected by Neurophobia may be less confident about diagnosing and treating patients with neurological disorders commonly encountered in primary care, such as headache, epilepsy and stroke ${ }^{13}$. A low degree of effective GP management of neurological diseases generates an excess of referrals to neurologists, thus overloading health systems.

In Brazil, the number of neurologists in underdeveloped regions, such as the Brazilian Amazon, is critically low ${ }^{14}$. Ac- for the management of common neurological disorders, such as headaches and epilepsy - Schon et al. used the metaphor "most people learn to drive safely with limited knowledge of how the engine works"2.

Other important reasons to Neurophobia were limited exposure to neurological patients and large number of complex and rare diagnoses, already described by other authors ${ }^{3,8}$. Limited exposure to patients is a direct consequence of the most suggested strategy to improve Neurology teaching: more bedside lectures. The association of complex and rare diagnoses with 
Neurophobia shows students have a misunderstanding of the most common neurological disorders, such as headaches, epilepsy and stroke, which frequently do not require several complementary exams and rarely involve differential diagnoses.

The main suggested methods to improve Neurology teaching, i.e. more and better bedside tutorials and traditional lectures, have also been reported in all other studies as the most important strategies to reduce Neurophobia. Online resources were seen as the least important method by students, an unexpected result for millennials, known as great users of the Internet. This finding corroborates a previous study ${ }^{3}$.

In his original article, Josefowicz attributed Neurophobia to the lack of integration between basic Neurosciences and clinical Neurology ${ }^{1}$. Our students also identified this issue as the main reason for Neurophobia and asked for more and better practical and expositive lectures. One third of all students specifically suggested a better integration between basic and clinical sciences. One author used a case-based teaching for undergraduate students and described an improvement in their perception of Neurology $y^{15}$, and a systematic review designed to evaluate the impact of new methodologies to prevent Neurophobia showed several different strategies and evidence of low quality in effective neurological education ${ }^{16}$.

However, Ridsdale et al. ${ }^{17}$ reported few changes as regards Neurophobia after a substantial curricular modification, which consisted in increased time and focus on Neurology. A recent article suggested that medical schools with 4-week Neurology internships and/or Neurology residencies had more graduates assuming Neurology residencies positions ${ }^{18}$. Therefore, increased practical contact with neurological patients and practical training of neurological skills also can improve the perception of Neurology among students. We believe both better integration of Neuroscience and Neurology and more practical neurological training can be key to preventing Neurophobia.

We expected the medical school to be capable of modifying previous misconceptions, acquired in family and society, about Neurology. Unfortunately, our data suggest Neurophobia is actually developed and caused by medical schools ${ }^{17}$.

This was the first study to analyze demographic predictors of Neurophobia. Our results suggest older female students involved in extracurricular activities were more likely to develop Neurophobia. Previous studies have not addressed these issues, but other authors have reported that male students are more confident in approaching patients with complex complaints, whatever the specialty; male students preferred Cardiology and female students showed a preference for Psychiatry ${ }^{17}$.
Our study had some limitations. The sample included students from only one state (Pará), and future Brazilian studies must include medical schools from other states, different regions and settings, for a national analysis of this problem. A low sample (18\%) of all Pará medical students can limit the generalization of these results, but an average response rate of $55 \%$ is similar to other studies ${ }^{4,6,9}$. We could not evaluate whether the overall quality of the medical school is correlated to the perceived difficulty of Neurology. Furthermore, no correlation was found between Neurophobia and the poor performance of students (written tests and patients care assessments). Possible institutional bias (differences across medical schools) and responder bias could not be totally excluded. The unbalanced high number of students from the pre-clinical stage $(n=224)$ and the low number of internship students ( $\mathrm{n}=95$ ), who have different practical experiences, may increase the bias in the overall data. To reduce this possible bias, we performed isolated analyses between medical school year groups.

\section{CONCLUSIONS}

In this study, we report the presence of Neurophobia in Brazil. Better integration between Neurosciences and Clinical Neurology and increased neurological practical activities are earmarked by the students as the actions required to improve their perception of Neurology. Further nationwide studies are needed. The Medical Education Commission of the Brazilian Academy of Neurology must be aware of this problem and propose guidelines on Neurology teaching at undergraduate level.

\section{ETHICS APPROVAL AND CONSENT TO PARTICIPATE}

Permission for the study was obtained from the Deans' Offices of the Medical Schools (Federal University of Pará, State University of Pará at Belém, State University of Pará at Santarém and University Center of Pará).

\section{ACKNOWLEDGMENTS}

We would like to thank the medical schools which approved execution of this study. We would also like to thank Henrique Alves Miranda for his assistance in the data collection, and Dr. Edienny Viana Santos-Lobato for reviewing the manuscript.

\section{REFERENCES}

1. Jozefowicz RF. Neurophobia: The fear of Neurology among medical students. Arch Neurol 1994;51:328-9.

2. Schon F, Hart P, Fernandez C. Is clinical neurology really so difficult? J NeurolNeurosurg Psychiatry 2002;72:557-9. 
3. Flanagan E, Walsh C, Tubridy N. 'Neurophobia' - Attitudes of medical students and doctors in Ireland to neurological teaching. Eur J Neurol 2007;14:1109-12.

4. Youssef FF. Neurophobia and its implications: evidence from a Caribbean medical school. BMC Medical Education 2009;9:39.

5. Sanya EO, Ayodele OE, Olanrewaju TO. Interest in neurology during medical clerkship in three Nigerian medical schools. BMC Medical Education 2010;10:36.

6. Zinchuk AV, Flanagan EP, Tubridy NJ, Miller WA, McCullough LD. Attitudes of US medical trainees towards neurology education: "Neurophobia" - a global issue. BMC Medical Education 2010;10:49.

7. Gupta NB, Khadilkar SV, Bangar SS, Patil TR, Chaudhari CR. Neurology as career option among postgraduate medical students. Ann Indian AcadNeurol 2013;16:478-82.

8. Matthias AT, Nagasingha P, Ranasinghe P, Gunatilake SB. Neurophobia among medical students and non-specialist doctors in Sri Lanka. BMC Medical Education 2013;13:164.

9. McCarron MO, Stevenson M, Loftus AM, McKeown P. Neurophobia among general practice trainees: The evidence, perceived causes and solutions. ClinNeurolNeurosurg 2014;122:124-8.

10. Pakpoor J, Handel AE, Disanto G, Davenport RJ, Giovannoni G, Ramagopalan SV. National survey of UK medical students on the perception of neurology. BMC Medical Education 2014;14:225.

11. Buonanotte MC, Riveros M, Villate S, Beltramini C, Buonanotte CF. Neurofobia o analfabetismo neurológico. Neuro1Arg 2016:8:3-7.

12. São Paulo State Regional CouncilofMedicine. MedicalDemography in Brazil2015.São Paulo, Brazil: 2015. Disponível em: http://www.usp.br/agen/wp-content/uploads/DemografiaMedica30nov2015.pdf. Accessed March 20, 2016.

13. World Health Organization. Atlas: Country Resources for Neurological Disorders. Geneva: WHO; 2004.

14. Santos-Lobato BL, Pontes-Neto OM. Shortage of neurologists in the Brazilian Amazon. Neurology 2015;85:1710-1.
15. Hudson JN. Linking neuroscience theory to practice to help overcome student fear of neurology. Med Teach 2006;28:651-3.

16. McColgan P, McKeown PP, Selai C, Doherty-Allan R, McCarron MO. Educational interventions in neurology: a comprehensive systematic review. Eur J Neurol 2013;20:1006-16.

17. Ridsdale L, Massey R, Clark L. Preventing neurophobia in medical students, and so future doctors. PractNeurol 2007;7:116-23.

18. Albert DA, Yin H, Amidei C, Dixit KS, Brorson JR, Lukas RV. Structure of neuroscience clerkships in medical schools and matching in neuromedicine. Neurology 2015;85:172-6.

\section{CONTRIBUTIONS}

Bruno Lopes Santos-Lobato was responsible for the study conception, which was refined by Átila Barros Magalhães, Diego Goes Moreira, Fredison Pinheiro Farias, Lara Khaled Porto, Rodrigo Bentes Pereira, Sávio Sérgio Custódio and Tiago Kiyoshi Kitabayashi Braga. All authors analyzed raw data. Bruno Lopes Santos-Lobato wrote the manuscript, with posterior edition provided by Átila Barros Magalhães, Diego Goes Moreira, Fredison Pinheiro Farias, Lara Khaled Porto, Rodrigo Bentes Pereira, Sávio Sérgio Custódio and Tiago Kiyoshi Kitabayashi Braga. All authors reviewed and approved the final manuscript.

\section{CONFLICT OF INTERESTS}

The authors declare that they have no competing interests.

\section{POSTAL ADDRESS}

Bruno Lopes Santos-Lobato

Av. Bandeirantes, 3900 - Ribeirão Preto

CEP 14049-900 - SP - Brazil

E-mail: bruls4@usp.br 